\title{
TINJAUAN YURIDIS TERHADAP ADOPSI ANAK WARGA NEGARA INDONESIA OLEH WARGA NEGARA ASING
}

\author{
Margaritha Rami Ndoen, Febi Meliana Ingratubun \\ Universitas Kristen Indonesia Paulus, itandoen@gmail.com
}

\begin{abstract}
Abstrak
Pengangkatan anak Indonesia oleh Warga Negara Asing merupakan salah satu upaya perlindungan anak bertujuan melindungi anak dan membahagiakan mereka dengan memiliki keluarga yang melindugi, mendidik, serta memberikan kasih sayang. Pasangan yang tidak mempunyai anak atau keturunan biasanya melakukan pengangkatan anak (Adopsi). Penelitian ini bertujuan untuk mengetahui bagaiman bentuk perlindungan hukum terhadap Anak Indonesia yang di Adopsi oleh WNA, dan bagaimana akibat hukumnya. Jenis Penelitian ini adalah penelitian Normatif, teknik pengumpulan data sekunder yang terdiri dari bahan hukum primer dan bahan hukum sekunder, data yang diperoleh diolah dengan menggunakan analisis Kualitatif. Hasil Penelitian menunjukkan bahwa bentuk perlindungan hukum terhadap anak Indonesia yang diadopsi oleh warga negara asing terdiri dari 2 (dua) macam perlindungan hukum yaitu perlindungan secara preventif dilakukan untuk mencegah terjadinya sengketa yang tercantum dari beberapa undang-undang. Sedangkan perlindungan secara represif dilakukan setelah terjadinya sengketa yakni yang tercantum dalam Undang-Undang Nomor 39 Tahun 1999 tentang HAM, Undang-Undang Nomor 23 Tahun 2002 tentang Perlindungan Anak, dan Undang-Undang Nomor 12 Tahun 2006 tentang Kewarganegaraan. Kata Kunci : Anak, Perlindungan, Adopsi
\end{abstract}

\begin{abstract}
The adoption of Indonesian children by foreigners is one of the child protection efforts aimed at protecting children and making them happy by having a family that protects, educates, and provides love. Couples who do not have children or descendants usually adopt children (adoption). This study aims to find out how the legal protection for Indonesian children adopted by foreigners is, and what the legal consequences are. This type of research is normative research, secondary data collection techniques consisting of primary legal materials and secondary legal materials, the data obtained are processed using qualitative analysis. The results of the study indicate that the form of legal protection for Indonesian children adopted by foreign nationals consists of 2 (two) kinds of legal protection, namely preventive protection is carried out to prevent disputes as listed in several laws. Meanwhile, repressive protection is carried out after the occurrence of disputes, namely those listed in Law No.39/1999 concering Human Rights, Law No.23/2002 concering Child Protection, and Law No.12/2006 concering Citizenship.
\end{abstract}

Keywords: Children, Protection, Adoption 


\section{Pendahuluan}

Perlindungan anak merupakan suatu upaya dimana setiap anak dapat melaksanakan hak dan kewajibannya sesuai dengan kemampuan yang dimilikinya ${ }^{1}$. Kehadiran Anak sebagai penerus garis keturunan akan diharapkan dapat menambah kebahagiaan pasangan suami isteri dalam komunitas kecilnya. Meskipun memperoleh keturunan bukanlah satu-satunya alasan membentuk perkawinan namun pada praktik ketidakhadiran seorang anak (keturunan) menjadi alasan ketidaksempuraan sebuah keluarga, dan sering menjadi alasan putusnya sebuah perkawinan (perceraian). Untuk mencegah putusnya perkawinan karena ketidakhadiran keturunan, maka dilakukanlah pengangkatan anak (Adopsi). ${ }^{2}$

Dalam pandangan umum, keluarga yang sempurna terdiri atas ayah, ibu, dan adanya anak ${ }^{3}$. Dengan demikian, keberadaan anak dalam keluarga merupakan suatu unsur penting sempurnanya suatu keluarga. Pengertian pengangkatan anak atau adopsi adalah suatu tindakan mengambil anak orang lain untuk dipelihara dan diperlakukan sebagai anak turunannya sendiri, berdasarkan ketentuan-ketentuan yang disepakati dan sah menurut hukum yang berlaku dimasyarakat yang bersangkutan. ${ }^{4}$

Fungsi utama dari adopsi adalah untuk melanjutkan keturunan dalam sebuah keluarga. Namun, setelah perang dunia kedua berkembang fungsi lain dari adopsi (pengangkatan anak) yaitu untuk mengurangi atau mengakhiri penderitaan atas kekurangan kebutuhan hidup serta pertumbuhan anak. Sehingga, yang pada mulanya adopsi hanya berfungsi untuk kepentingan bagi pihak yang mengangkat anak (adoptant), maka sekarang fungsi adopsi tersebut berubah menjadi fungsi sosial kemanusiaan ${ }^{5}$

Pengertian Anak Angkat dalam Peraturan Pemerintah Republik Indonesia Nomor 54 tahun 2007 tentang Pelaksanaan Pengangkatan Anak adalah anak yang haknya dialihkan dari lingkungan kekuasaan keluarga orang tua, wali yang sah, atau orang lain yang bertanggung jawab atas perawatan, pendidikan, dan membesarkan anak tersebut, ke dalam lingkungan keluarga orangtua angkatnya berdasarkan keputusan atau penetapan pengadilan. Dan dalam Pasal 1 ayat (2) Peraturan Pemerintah Republik Indonesia Nomor 54 Tahun 2007 tentang Pelaksanaan Pengangkatan Anak disebutkan bahwa "Pengangkatan Anak adalah suatu perbuatan hukum yang mengalihkan seorang anak dari lingkungan kekuasaan

\footnotetext{
${ }^{1}$ Arif Gosita. 1984. Masalah Perlindungan Anak. CV Akademika Pressindo. Jakarta, hlm. 10

${ }^{2}$ Muhammad Dwimas Ardhin Nasution, 2019. Akibat Hukum Pengangkatan Anak Warga Negara Indonesia Oleh Warga Negara Asing (Intercountry Adoption), Studi Dinas Sosial Provinsi Sumatera Utara, Skripsi Hukum. Fakultas Hukum Universitas Sumatra Utara, hlm.2

${ }^{3}$ Gatot Soemartono, 2006, Arbitrase dan Mediasi di Indonesia, PT. Gramedia Pustaka Utama, Jakarta, hlm. 2.

${ }^{4}$ Arif Gosita. 1989. Masalah Perlindungan Anak, Akademi Pressindo, Jakarta, hlm 44.

${ }^{5}$ Sudargo Gautama (Gouw giok siong), 1969, Hukum Perdata Internasional Indonesia. Kinta. Jakarta, hlm. 95.
} 
orangtua, wali yang sah atau orang lain yang bertanggung jawab atas perawatan, pendidikan dan membesarkan anak tersebut ke dalam lingkungan keluarga orangtua angkat".

Pengangkatan anak yang terjadi sering kita ketahui dilakukan sesuai peraturan yang berlaku dan namun tidak jarang juga dilakukan dengan illegal yaitu melalui perdagangan bayi seperti yang kita lihat di berbagai media massa. Jenis pengangkatan anak diatur dalam Peraturan Pemerintah Nomor 54 Tahun 2007 Pasal (7) yang menyebutkan bahwa Pengangkatan anak terdiri atas pengangkatan anak antar Warga Negara Indonesia, dan pengangkatan anak antara Warga Negara Indonesia dengan Warga Negara Asing.

Proses pengangkatan anak oleh Warga Negara Asing (Intercountry Adoption) tidaklah sama dengan proses pengangkatan anak antar warga negara Indonesia. Pengangkatan anak antar warga negara bisa diakukan berdasarkan hukum adat yang berlaku di daerah tertentu walaupun pada dasarnya haruslah tetap memerlukan suatu penetapan yang sah dari pengadilan untuk status anak angkat di kemudian hari. Sedangkan, pengangkatan anak terhadap warga negara Indonesia oleh warga negara Asing harus melalui Lembaga Pengasuhan Anak atau Yayasan Panti Asuhan yang ditunjuk oleh Departemen Sosial untuk melakukan Intercountry Adoption. 6

Pengangkatan anak dilakukan oleh Lembaga Pengasuhan Anak dan diatur dalam ketentuan umum angka 6 Keputusan Menteri Sosial Nomor 40/HUK/KEP/IX/1980 tentang Organisasi Sosial yang menyatakan bahwa7: “Organisasi Sosial/Lembaga Sosial adalah lembaga kesejahteraan sosial yang berbadan hukum yang menangani pengasuhan anak yang ditunjuk oleh Dinas Sosial melalui Surat Keputusan Menteri Sosial sebagai penyelenggara pengangkatan anak". Sehingga proses pengangkatan anak tersebut berbeda dengan proses pengkatan anak antar warga negara yang bisa dilakukan berdasarkan kebiasaan yang terdapat di daerah tertentu, walaupun dalam beberapa hal terdapat proses yang sama dalam memperoleh hubungan hukum yang sah antara orang tua angkat dengan anak angkat.

Pengangkatan anak warga negara Indonesia oleh warga negara Asing yang lebih dikenal dengan Intercounty Adoption ini memiliki proses pengangkatan yang lebih sulit dan rumit dari pengangkatan anak pada umumnya. Calon anak angkat harus berada di lembaga pengasuhan anak, dengan kata lain anak yang akan diangkat oleh warga negara Asing tidak boleh diserahkan langsung oleh orang tua kandung si anak. Sehingga berdasarkan permasalahan yang timbul akibat

\footnotetext{
6 Muderis Zaini, 2002, Adopsi Suatu Tinjauan dari Segi Tiga Sistem Hukum, Bina Akasara, Jakarta, hlm.15

${ }^{7}$ Keputusan Menteri Sosial Nomor 40/HUK/KEP/IX/1980 tentang Organisasi Sosial (diakses tanggal 20 April 2021)
} 
pengangkatan anak Warga Negara Indonesia oleh Warga Negara Asing (Intercountry Adoption) sangatlah menarik untuk diteliti lebih jauh berdasarkan Undang-Undang yang berlaku dan proses secara langsung di lapangan.

\section{Metode}

Jenis penelitian yang di gunakan dalam penelitian ini adalah penelitian hukum Normatif. Penelitian ini menggunakan Data Sekunder yang terdiri dari bahan hukum primer dan bahan hukum sekunder. Bahan Hukum Primer berupa Undang-Undang Nomor 23 Tahun 2002 tentang Perlindungan Anak, Kepres Nomor 36 Tahun 1990 tentang Konvensi Hak-Hak Anak, Undang-Undang Nomor 23 Tahun 2006 tentang Administrasi Kependudukan, Peraturan Pemerintah Nomor 54 Tahun 2007 tentang Pelaksanaan Pengangkatan Anak, dan baham hukum Sekunder berupa Buku, Jurnal, artikel terkait. Data yang diperoleh kemudian diolah menggunakan analisis kualitatif.

\section{Perlindungan hukum terhadap Anak Warga Negara Indonesia Yang Di Adopsi Oleh Warga Negara Asing}

Anak memiliki hak dan kewajiban yang sama pada umumnya yang memerlukan suatu perlindungan hukum. Perlindungan itu sendiri adalah suatu perlindungan yang diberikan terhadap subyek hukum dalam bentuk perangkat hukum yang bersifat preventif maupun represif yang menjadi suatu gambaran dari fungsi hukum yaitu adanya keadilan, ketertiban, kepastian, kemanfaatan, dan kedamaian. ${ }^{8}$ Perlindungan juga menjadi sebuah pengakuan terhadap hak asasi manusia yang dimiliki oleh subyek hukum dalam negera hukum agar terhindar dari kesewenang-wenangan ${ }^{9}$,maka para aparat membuat suatu peraturan mengenai perlindungan hukum khusus untuk anak-anak yakni perlindungan anak.

Bentuk perlindungan hukum terhadap anak Indonesia yang diadopsi oleh warga negara asing terdiri dari 2 (dua) macam perlindungan hukum macam yaitu perlindungan secara preventif dilakukan untuk mencegah terjadinya sengketa yang tercantum dalam beberapa pasal dari beberapa undang-undang yaitu pasal 21 dan pasal 25 dalam Kepres No.36 Tahun 1990 tentang Konvensi Hak-Hak Anak, pasal 41 dan pasal 43 ayat 2 dalam Undang-Undang No.23 Tahun 2002 tentang Perlindungan Anak, pasal 47 UU No.23 Tahun 2006 tentang Administrasi Kependudukan, pasal 12, pasal 13, pasal 22, pasal 27, pasal 28, pasal 29, pasal 30, dan pasal 32 dalam PP No.54 Tahun 2007 tentang Pelaksanaan Pengangkatan Anak, kemudian pasal 47 dalam Undang-Undang No.23 Tahun 2006 tentang Administrasi Kependudukan,

\footnotetext{
8 Rahayu, Hukum Pengangkatan Orang, dalam http:/www.prasko.com/2011/02/pengertianperlindunganhukum.html, (diunduh pada hari kamis, 20 April 2021)

${ }^{9}$ Philipus M. Hadjon, 1987, Perlindungan Hukum Bagi Rakyat Indonesia, Bina Ilmu, Surabaya, hIm.205
} 
pasal 4, pasal 5, pasal 36, pasal 38, pasal 39, pasal 40, pasal 41 dalam pengangkatan anak Indonesia oleh yang salah satunya warga negara asing kemudian pasal 44, pasal 45, pasal 46 merupakan pasal-pasal yang mencakup pengangkatan anak Indonesia oleh warga negara asing. Sedangkan perlindungan secara represif dilakukan setelah terjadinya sengketa yakni yang tercantum dalam pasal 66 angka 5, 6, dan 7 dalam Undang-Undang No.39 Tahun 1999 tentang HAM, kemudian pasal 77, pasal 79, dan pasal 83 dalam Undang-Undang No.23 Tahun 2002 tentang Perlindungan Anak, dan pasal 36 UU No.12 Tahun 2006 tentang Kewarganegaraan. ${ }^{10}$ Pasal-pasal yang ada diharapkan dapat digunakan untuk bukan hanya untuk melindungi melainkan melaksanakan pengangkatan anak Indonesia oleh warga negara asing agar tidak terjadi permasalahan.

Upaya perlindungan anak tidak hanya dilakukan oleh keluarga sang anak sendiri, namun perlindungan juga dilakukan oleh masyarakat, lembaga pemerintah maupun lembaga swastayang bertujuan untuk mengupayakan pengamanan dan pemenuhan kesejahteraan setiap anak baik fisik, mental maupun sosialnya sesuai dengan kebutuhan setiap anak ${ }^{11}$. Perlindungan anak dari keluarga merupakan perlindungan yang diberikan dari orang-orang terdekatnya agar si anak dapat memenuhi kewajibannya serta mendapatkan apa yang menjadi haknya, selain itu keluarga memelihara dan mendidik agar si anak dapat menjadi anak yang baik. Sedangkan negara (pemerintah maupun lembaga lainnya) melindungi kesejahteraan anak, baik dari segi jasmani, rohani, pendidikan, ekonomi, sosial serta kehidupan yang dijalaninya untuk menggapai cita-cita. Begitu pula dengan anak angkat yang merupakan anak orang lain yang dianggap anak sendiri oleh orang tua angkat dengan resmi menurut hukum adat setempat, dikarenakan tujuan untuk kelangsungan keturunan dan atau pemeliharaan atas harta kekayaan rumah tangga12, mereka juga memerlukan perlindungan karena anak angkat merupakan bagian baru bagi sebuah keluarga yang tidak ataupun belum dikaruniai seorang anak.

Di Indonesia pengangkatan anak sudah menjadi sebuah lembaga resmi untuk terlindunginya anak angkat, karena pada saat ini banyak sekali modus kejahatan pengangkatan anak dengan alasan simpati kepada anak tersebut yang tidak memiliki orang tua, orang tuanya tidak mampu, maupun dengan alasan ingin menjadikan anak tersebut sebagai penerus keluarga, namun dalam kenyataannya anak tersebut disia-siakan oleh keluarga angkatnya. Indonesia telah mengenal pengangkatan anak antar negara setelah pengesahan SEMA No.2 Tahun 1979,

\footnotetext{
${ }^{10}$ Oeke Reva Ade Pratiwi, 2014, Wujud Perlindungan Hukum Bagi Anak Indonesia Yang Diadopsi Oleh Warga Negara Asing Dalam Hukum Positif Di Indonesia, Jurnal Ilmiah Skripsi hukum. Fak Hukum Universitas Brawijaya. hlm.17

${ }^{11}$ Arif Gosita, 1984, Masalah Perlindungan Anak, CV Akademika Pressindo, Jakarta, hlm.10

12 R. Soeroso, 2010, Perbandingan Hukum Perdata, Sinar Grafika, Jakarta, hlm. 175
} 
namun pengangkatan anak antar negara menimbulkan permasalahan baru yakni mengenai status personal merupakan kondisi keadaan suatu pribadi dalam hukum yang diberikan/diakui oleh negara untuk mengamankan dan melindungi lembagalembaganya ${ }^{13}$, dan untuk menetukan penentuan status personal ada beberapa azas, yakni $^{14}$ :

a. Azas Nasionalitas atau Kewarganegaraan (Lex Patriae)

Merupakan hukum personil dari seseorang adalah hukum nasionalnya, hukum yang ditentukan oleh kewarganegaraannya. Setiap warga negara ini tetap takhluk di bawah hukum nasional negaranya kemanapun ia pergi.

b. Azas Teritorialitas atau Domisili (Lex Domicili)

Merupakan status personal suatu pribadi tunduk pada hukum dimana ia berdomisili.

c. Azas Lex Loci Celebrations

Merupakan hukum yang mengatur dimana tempat dilangsungkannya sebuah perkawinan dan dua orang mempelai harus tunduk kepada formalitas formalitas setempat.

d. Lex Fori (tempat Gugatan)

Yaitu apabila obyek gugatan benda bergerak maka dalam hal mengajukan gugatan berdasarkan dimana beda bergerak tersebut berada.

Adapula ketentuan yang tercantum dalam Pasal 16 AB yang mengatur status personal yaitu ketentuan-kententuan perundang-undangan mengenai status dan wewenang orang-orang tetap mengikat untuk kaula-kaula negara Belanda jikalau mereka berada di luar negeri. Ataupun kewarganegaraan dari calon anak angkat yang berbeda dari calon orang tua angkatnya, ada azas-azas yang mempengaruhi kewarganegaraan yaitu: 15

a. Asas ius sanguinis (law of the blood), adalah asas yang menentukan kewarganegaraan seseorang berdasarkan keturunan, bukan berdasarkan negara tempat kelahiran.

b. Asas ius soli (law of the soil) secara terbatas, adalah asas yang menentukan kewarganegaraan seseorang, berdasarkan negara tempat kelahiran, yang diberlakukan terbatas bagi anak-anak sesuai dengan ketentuan yang diatur dalam Undang-Undang.

c. Asas kewarganegaraan tunggal, adalah asas yang menentukan satu kewarganegaraan bagi setiap orang.

\footnotetext{
${ }^{13}$ Aminah, 2018, Pengangkatan Anak Internasional Di Indonesia, Diponegoro Private Law Review, Volume 2 Nomor 1, hlm. 230

${ }^{14}$ Oeke Reva Ade Pratiwi, Op.cit, hlm. 5

15 Ibid, hlm. 6
} 
d. Asas kewarganegaraan ganda terbatas adalah asas yang menentukan kewarganegaraan ganda bagi anak-anak sesuai dengan ketentuan yang diatur dalam Undang-Undang.

Kemudian adanya penyempurnaan dari SEMA No.2 Tahun 1979 yakni SEMA No.6 Tahun 1983. Dan pada tahun 1990 Indonesia mengikuti konvensi yang diikuti oleh beberapa negara juga dengan tema hak-hak anak dimana hal itu untuk menggupayakan perlindungan bagi anak pada umumnya serta bagi negara yang mengakui sistem pengangkatan anak juga perlu melindungi calon anak angkat. Kemudian adanya pengkhususan perlindungan bagi anak merupakan implementasi dari KHA No.36 Tahun 1990 yaitu UU No.23 Tahun 2002 tentang Perlindungan Anak dimana beberapa menjelaskan mengenai anak angkat yang berhak tahu asal-usul mereka serta pemerintah memberi pengarahan bagi calon orang tua angkat khususnya warga negara asing yang ingin mengangkat anak berkewarganegraan Indonesia, disamping itu pula UU No.23 Tahun 2002 juga mencantumkan pasalpasal bagi calon orang tua angkat yang melakukan tindak kejahatan terhadap anak angkatnya dapat dikenai sanksi. Sehingga bagi calon orang tua angkat yang ingin mengangkat anak berkewarganegaraan Indonesia harus memenuhi baik persyaratan materiil maupun administrasi yang tercantum dalam PP No.54 Tahun 2007 tentang Pelaksanaan Pengangkatan Anak serta Peraturan Menteri No.110 Tahun 2009 tentang Persyaratan Pengangkatan Anak.

\section{Akibat Hukum Yang Terjadi Terhadap Pengangkatan Anak Warga Negara Indonesia Oleh Warga Negara Asing}

Setiap perbuatan hukum pasti memiliki akibat hukum. Demikian terhadap pengangkatan anak yang akhirnya akan memperoleh hubungan hukum yang baru. Statblaat Tahun 1917 Nomor 129 Tentang Adopsi menjelaskan akibat hukum terhadap pengangkatan anak. ${ }^{16}$ Sesuai dengan Pasal 11 bahwa anak adopsi secara hukum mempunyai nama keturunan dari orang tua yang mengadopsi. Sesuai dengan pasal 12 ayat (1) bahwa anak adopsi dijadikan sebagai anak yang dilahirkan dari orang tua yang mengadopsi, konsekuensinya, anak yang diadopsi menjadi ahli waris dari orang tua yang mengadopsi. Terhadap pasal 12 tersebut J. Satrio berkomentar, konsekuensi lebih lanjut adalah bahwa karena dianggap dilahirkan dari perkawinan yang mengadopsi, maka dalam keluarga adoptan, adoptandus berkedudukan sebagai anak sah dengan konsekuensi lebih lanjut. ${ }^{17}$ Bila anak adopsi dianggap dilahirkan dari perkawinan orang tua angkat anak adoptandus berkedudukan sebagai anak sah, maka akibat hukumnya sebagai berikut :

\footnotetext{
${ }^{16}$ H. Ahmad Kamil dan H.M. Fauzan, 2008, Hukum Perlindungan dan Pengangkatan Anak Di Indonesia, Raja Grafindo Pesada, Jakarta, hlm. 22-29.

17 J. Satrio, 2000, Hukum Keluarga Tentang Kedudukan Anak Dalam Undang-Undang, Citra Aditya Bakti, Bandung, hlm, 236.
} 
a. Kekuasaan orang tua terhadap pribadi anak yaitu orang tua wajib memelihara mendidik sekalian anak mereka yang belum dewasa sepanjang perkawinan bapak dan ibu dari tiap-tiap anak sampai ia menjadi dewasa, tetap dibawah kekuasaan orang tua sepanjang kekuasaan orang tua belum dicabut.

b. Kekuasaan orang tua terhadap harta kekayaan anak, yaitu terhadap anak yang belum dewasa maka orang tua harus mengurus harta kekayaan anak itu.

c. Hak dan kewajiban anak terhadap orang tua, yaitu tiap-tiap anak dalam umur berapa pun wajib menaruh kehormatan dan keseganan terhadap bapak ibunya serta berhak atas pemeliharaan dan pendidikan. Adanya adopsi maka terputus segala hubungan keperdataan antara anak adopsi dengan orang tua kandungnya. Undang-undang nomor 23 tahun 2002 tentang perlindungan anak menyebutkan :

1) Pengangkatan anak hanya dapat dilakukan untuk kepentingan yang terbaik bagi anak dan dilakukan berdasarkan adat kebiasaan setempat dan ketentuan peraturan perundang-undangan yang berlaku.

2) Pengangkatan anak tidak memutuskan hubungan sedarah dengan orang tua kandung

3) Calon orang tua angkat harus seagama dengan agama yang dianut oleh calon anak angkat.

4) Pengangkatan anak oleh warga Negara asing hanya dapat dilakukan sebagai upaya terakhir

5) Dalam hal asal usul anak didik diketahui, maka agama anak disesuaikan dengan agama mayoritas penduduk setempat.

6) Orang tua angkat wajib memberitahukan pemberitahuan asal usul dan orang tua kandungnya dilakukan dengan memperhatikan kesiapan anak yang bersangkutan.

Dari bunyi pasal diatas bahwa pengangkatan anak yang dilakukan dengan adat maupun penetapan pengadilan tidak boleh memutus hubungan darah antara anak angkat dengan orang tua kandungnya yang bertujuan antara lain untuk mencegah terjadinya perkawinan sedarah. Oleh karena itu untuk menghindari hal-hal yang tidak diinginkan terhadap anak angkat maka orang tua angkat harus mempunyai data yang jelas mengenai asal usul keluarga anak angkat dan pada saat yang tepat wajib memberitahukan kepada anak angkatnya. Dalam pengangkatan anak bukan saja syarat-syarat untuk adopsi yang berbeda, tetapi akibat-akibat hukum pun berbeda. 18

Adoptio plena, yaitu pengangkatan anak yang syaratnya berat, dan akibat hukum berpengaruh banyak. Pengangkatan anak tersebut memutus hubungan hukum anak angkat dengan orang tua biologisnya, serta melanjutkannya dengan

${ }^{18}$ Sudargo Gautama, 1995, Hukum Perdata Internasional Indonesia, Binacipta, Bandung, hlm.138 
orang tua angkatnya. Akibat hukumnya, anak tersebut memiliki hak waris orang tua angkat dan tidak lagi memiliki hak waris dari orang tua kandungnya. Adoptio minus plena, yaitu pengangkatan anak yang syaratnya gampang dan akibat hukum tidak terlalu berpengaruh banyak. Pengangkatan anak tersebut hanya bertujuan memelihara anak dan tidak memutus hubungan anak angkat dengan orang tua kandungnya, serta anak angkat tidak memiliki hak waris dari orang tua angkat.

Pada dasarnya pengangkatan anak adalah berubahnya status anak angkat menjadi anak kandung yang sah dengan segala hak dan kewajibannya/, Hal ini mengakibatkan putusnya hubungan orang tua kandung dengan anak (adoptio plena). Akan tetapi, apabila pengangkatan anak dilakukan di Pengadilan Agama maka akibat hukum yang terjadi adalah adoptio minus plena, karena telah jelas disebutkan bahwa Hukum Islam melarang pengangkatan anakdan melarang akibat hukum yang memutus hubungan dengan orang tua kandung. Walaupun sebelum pelaksanaan pengangkatan anak tersebut calon orang tua angkat sudah melewati dan memenuhi persyaratan yang ketat. Hal ini dimaksudkan agar kesejahteraan anak angkat dapat terjamin, karena tujuan utama pengangkatan anak adalah kepentingan terbaik bagi si anak. Penulis akan menjabarkan akibat hukum dari pelaksanaan pengangkatan anak khususnya pengangkatan anak Warga Negara Indonesia oleh Warga Negara Asing dari berbagai aspek.

Pada prinsipnya Indonesia menganut asas ius sanguinis yaitu hak kewarganegaraan yang diperoleh oleh sesorang berdasarkan kewarganegaraan ayah atau ibu biologisnya. Akibat hukum yang terjadi terhadap pengangkatan anak Warga Negara Indonesia oleh Warga Negara Asing ada 2 (dua) yaitu:

a. Anak angkat memiliki 2 (dua) kewarganegaraan yaitu kewarganegaraan Indonesia dan kewarganegaraan orang tua angkatnya, sampai anak berusia 18 (delapan belas) tahun.

b. Anak angkat mempunyai hak yang sama dengan anak kandung, dimana kedudukan keduanya sama dalam hal kewarisan.

Oleh karena itu, untuk warga yang orang tuanya telah menjadi warga negara Indonesia, maka dia otomatis menjadi Warga Negara Indonesia. Dalam UndangUndang No. 12 Tahun 2006 memang tidak dibenarkan seseorang memiliki 2 (dua) kewarganegaraan. Tetapi untuk anak-anak ada pengecualian, dengan catatan setelah anak berusia 18 (delapan belas) tahun dia harus memilih status kewarganegaraannya. Hal tersebut dijelaskan dalam Undang-undang No. 12 Tahun 2006 Tentang Kewarganegaraan Republik Indonesia, Pasal 6 yang menyebutkan bahwa: "Dalam hal status Kewarganegaraan Republik Indonesia terhadap anak sebagaimana disebut dalam Pasal 4 huruf c, huruf d, huruf h, huruf 1, dan Pasal 5 akibatnya anak berkewarganegaraan ganda, setelah berusia 18 (delapan belas) tahun 
atau sudah kawin anak tersebut harus menyatakan memilih salah satu kewarganegaraannya".

Berdasarkan bunyi Pasal 6 yang telah disebutkan di atas maka dijelaskan anak yang mendapat kewarganegaraan ganda adalah:

a. Anak yang lahir dari perkawinan yang sah dari seorang ayah Warga Negara Indonesia dan ibu warga negara asing (Pasal 4 huruf c, UU No. 12 Tahun 2006);

b. Anak yang lahir dari perkawinan yang sah dari seorang ayah warga negara asing dan ibu Warga Negara Indonesia (Pasal 4 huruf d, UU No. 12 Tahun 2006);

c. Anak yang lahir di luar perkawinan yang sah dari seorang ibu warga negara asing yang diakui oleh seorang ayah Warga Negara Indonesia sebagai anaknya dan pengakuan itu dilakukan sebelum anak tersebutberusia 18 (delapan belas) tahun atau belum kawin (Pasal 4 huruf h, UU No. 12 Tahun 2006);

d. Anak yang dilahirkan di luar wilayah negara Republik Indonesia dari seorang ayah dan ibu Warga Negara Indonesia yang karena ketentuan dari negara tempat anak tersebut dilahirkan memberikan kewarganegaraan kepada yang bersangkutan (Pasal 4 huruf 1, UU No. 12 Tahun 2006).

e. Anak Warga Negara Indonesia yang belum berusia 5 (lima) tahun diangkat secara sah sebagai anak oleh warga negara asing berdasarkan penetapan pengadilan tetap diakui sebagai Warga Negara Indonesia (Pasal 5 ayat (2), UU No. 12 Tahun 2006).

\section{Kesimpulan}

Bentuk perlindungan hukum terhadap anak Indonesia yang diadopsi oleh warga negara asing terdiri dari 2 (dua) macam perlindungan hukum macam yaitu perlindungan secara preventif dilakukan untuk mencegah terjadinya sengketa. Dan Represif dilakukan seteleah terjadinya sengketa atau perbuatan melawan hukum. Akibat hukum yang terjadi terhadap pengangkatan anak Warga Negara Indonesia oleh Warga Negara Asing ada 2 (dua) yaitu:

a. Anak angkat memiliki 2 (dua) kewarganegaraan yaitu kewarganegaraan Indonesia dan kewarganegaraan orang tua angkatnya, sampai anak berusia 18 (delapan belas) tahun.

b. Anak angkat mempunyai hak yang sama dengan anak kandung, dimana kedudukan keduanya sama dalam hal kewarisan.

\section{Referensi}

Arif Gosita, 1984, Masalah Perlindungan Anak, CV Akademika Pressindo, Jakarta. Aminah, 2018, Pengangkatan Anak Internasional Di Indonesia, Diponegoro Private Law Review Volume 2, Nomor 1. 
Gatot Soemartono, 2006, Arbitrase dan Mediasi di Indonesia, PT. Gramedia Pustaka Utama, Jakarta.

H. Ahmad Kamil dan H.M. Fauzan, 2008, Hukum Perlindungan dan Pengangkatan Anak Di Indonesia, Raja Grafindo Persada, Jakarta.

J. Satrio, 2000, Hukum Keluarga Tentang Kedudukan Anak Dalam Undang-Undang, Citra Aditya Bakti. Bandung.

Muderis Zaini, 2002, Adopsi Suatu Tinjauan dari Segi Tiga Sistem Hukum, Bina Akasara, Jakarta.

Muhammad Dwimas Ardhin Nasution, 2019, Akibat Hukum Pengangkatan Anak Warga Negara Indonesia Oleh Warga Negara Asing (Intercountry Adoption) Studi Dinas Sosial Provinsi Sumatera Utara, Skripsi Hukum. Fakultas Hukum Universitas Sumatra Utara

Philipus M. Hadjon, 1987, Perlindungan Hukum Bagi Rakyat Indonesia, Bina Ilmu, Surabaya.

Oeke Reva Ade Pratiwi, 2014, Wujud Perlindungan Hukum Bagi Anak Indonesia Yang Diadopsi Oleh Warga Negara Asing Dalam Hukum Positif Di Indonesia, Jurnal Ilmiah Skripsi Hukum, Fakultas Hukum Universitas Brawijaya.

R. Soeroso, 2010, Perbandingan Hukum Perdata, Sinar Grafika, Jakarta.

Sudargo Gautama (Gouw giok siong), 1969, Hukum Perdata Internasional Indonesia, Kinta, Jakarta.

Rahayu, Hukum Pengangkatan Orang, dalam http:/www.prasko.com/2011/02/pengertianperlindungan-hukum.html, (diunduh pada hari kamis, 20 April 2021) 